\title{
Studies on NOx removal using Dunaliella salina algae in photobioreactors
}

\author{
Kethineni Chandrika', S. F. Choragudi ${ }^{2}$, Krishna Kireeti Kakarla ${ }^{3}$, Kolluru Sumanth ${ }^{4}$ and \\ Ch Devika ${ }^{5}$ \\ ${ }^{1}$ Associate Professor, Department of Biotechnology, Koneru Lakshmaiah Education Foundation, \\ Vaddeswaram, Guntur, AP, India-522502 \\ 2,3,4,5 Department of Biotechnology, Koneru Lakshmaiah Education Foundation, Vaddeswaram, Guntur, AP, \\ India-522502
}

\section{ABSTRACT}

The capability of an algal species to remove NO2 and NO in the simulated flue gas was established using Dunaliella salina in Photobioreactors under two variants of NOx sources. The concentrations studies were in the range between $25 \mathrm{ppm}$ to $150 \mathrm{ppm}$. The diffusion of NOx and subsequent reaction with water resulted in NO3- and N02- in the growth medium. Algal growth by absorption of NO3- and NO2- created a nitrate gradient in the bulk medium resulting in NOx uptake rates from the gas phase of up to 96\%, leaving the unconsumed nitrogen of up to $7 \mathrm{mg}-\mathrm{N} / \mathrm{L}$ in the growth medium. Algal species having an initial cell density of $2.8 \times 105$ cells $/ \mathrm{mL}$ grew to the cell density of $1.73 \times 107$ cells $/ \mathrm{mL}$ and dry weight of $262 \mathrm{mg} / \mathrm{L}$. The Nitrogen content of cells varied from 3-6\%. The treatment of NOx in Photobioreactors was investigated with reference to the gas removal efficiency, cell growth and total nitrogen content in the biomass

KEY WORDS: DUNALIELLA SALINA, PHOTOBIOREACTORS, ALGAL GROWTH

\section{INTRODUCTION}

Disproportionate usage of fossil fuels has been considered as the source for manmade toxic emissions comprising carbon dioxide, sulfur dioxide, nitrogen oxides, volatile organic compounds and heavy metals (Mulhol-

\section{ARTICLE INFORMATION:}

Corresponding Authors: kkchandrika@kluniversity.in Received $19^{\text {th }}$ Oct, 2018

Accepted after revision $24^{\text {th }}$ Dec, 2018

BBRC Print ISSN: 0974-6455

Online ISSN: 2321-4007 CODEN: USA BBRCBA Thomson Reuters ISI ESC / Clarivate Analytics USA

: Mono of Clarivate Analytics and Crossref Indexed Journal Mono of $C R$

NAAS Journal Score 2018: 4.31 SJIF 2017: 4.196

- A Society of Science and Nature Publication, Bhopal India 2018. All rights reserved.

Online Contents Available at: http//www.bbrc.in/

DOI: $10.21786 / \mathrm{bbrc} / 11.4 / 18$ land, 2008; Attilo et al., 2009). The by-products of fossil fuels have been identified as one of the major anthropogenic sources of this gas, contributing to global warming by the greenhouse effect. Therefore, it has become obligatory to reduce these toxic emissions before they are disposed into the environment. Nitric oxide (NO) and 
Nitrogen dioxide (NO2) are the two main components that make up NOx. These components are toxic and have various environmental hazards as per Environmental Protection Agency (Ronda, 2014). The nitrogen removal is $94.9 \%$ in the ammonium form nitrogen group using biofilm (Yuxuan Zhu 2018).

There are several methods for treatment of NOx. Selective catalytic reduction (SCR) is used, however it is more expensive when applied for large-scale power plants (Miller et al., 2010). Another way to treat NOx from stationary sources is to use scrubbers to transfer the risk into an aqueous solution, which still must be treated or disposed of (Raja et al., 2007). Hence, to develop an economical and practical process to handle NOx exists. Cultivation of an algae to take up dissolved NOx from a scrubber as a nitrogen source, and oxygen only released as a by-product. This concept has been worked to estimate that, algal strains and conditions, algae can take up nitrogen from dissolved NOx (Nagase et al., 1997). Toxic compounds present in the flue gas inhibit the growth rate. NO2 has high solubility in water and therefore, reacts with water to form aqueous nitrates (NO3) and nitrites (NO2), some of the unaccounted-for nitrogen was lost due to volatization of gaseous nitrogen species, (Kaitlyan 2018).

Aqueous nitrate and nitrites are used by the algae as a source of nitrogen for cell synthesis, (Mulholland \& Lomas, 2008). The dissolved NO2 and NO react to form dissolved nitrogen compounds which are available to ingest, biological conditions for the uptake of nitrate or nitrite by the algae, (Lee \& Schwartz 1981). The nitrate or nitrite uptake by the algae reduce the soluble N02, thus increases the concentration gradient of NO2 between liquid and the air. Thus, apparent solubility of NO2 is proportional to the NO2 gradient in the bulk medium, (Skalska, et al 2010). Nitrogen mono-oxide and sulfur dioxide can be removed by simultaneous absorption into aqueous mixed solutions of sulfite and [Fe II (edta)]H20)]2-, ferrous ion coordinated to an anion of ethylene-diaminetetraacetic acid, (Tomasz et al 2016). A sequential process for the recovery and purification of multiple products was used on a mixture of algal biomass comprised of Spirulina platensis and Dunaliella salina (Kethineni 2017).

Dunaliella salina is a green algae known to with stand high salinity and accumulate carotenes. The nitrate requirement for algae is more for accumulation of biomass than for accumulation of carotene. Nitrates in the range of $1-10 \mathrm{mM}$ is suitable for algal growth (Tafreshi et al., 2009). Harter et al, (2012) performed a mass balance for nitrogen from NOx for Dunaliella cultures in a column reactor. In a lab scale trail under simulated flue gas the results indicate that with an inflow of
$150 \mu \mathrm{g} \mathrm{N} / \mathrm{L}$ day NOX along with CO2 the alga could able to maintain a net influx of $0.52 .73 \mu \mathrm{g} \mathrm{N} \mathrm{L-1} \mathrm{d-1} \mathrm{which}$ amounts to 35\% NOx removal. Nagase et al, (1997) studied the removal rate of nitric oxide by Dunaliella tertiolacta supplied in the range between 25-500ppm. At an inlet concentration of 500ppm NO in addition to $\mathrm{CO} 2$, it was shown to remove $110 \mu$ moles per hour at a flow rate of $150 \mathrm{~mL} / \mathrm{min}$. Also, it was shown that within a range of 100 to $400 \mathrm{~mL} / \mathrm{min}$ gas flow rate, a maximum of $60 \%$ of the NO was removed. These results suggest that $D$. salina is a potential algal species for NOx removal. the ability of the green algae, Chlorella to acclimate to high level of NOx and the potential usage of Chlorella strains in biological NOx removal (DeNOx) from industrial flue gases, (Tianpei and Gang Xu 2016). To understand the NOX removal process and to increase its range of applicability. The use of microalgae for simultaneous removal of $\mathrm{CO}_{2}, \mathrm{SO}_{\mathrm{x}}$ and $\mathrm{NO}_{\mathrm{x}}$ from flue gas is an environmentally benign process, (Hong-Wei Yen et al, 2016), 75\% decrease of the nitrogen concentration in the medium, with respect to the optimal values for growth, increased the lipid fractions of algal species, (Attilio Converti et al 2009).

It is very important to undertake biological $\mathrm{NO}_{\mathrm{x}}$ fixation. Therefore, in this work, two individual experiments were conducted to productively remove the NOx from simulated flue gas with varying NOx loading rates by estimating the optimal growth parameters. Different NOx concentrations were supplied to each photobioreactor inoculated with Dunaliella salina. NOx removal efficiency and algal growth were determined in each experiment.

\section{MATERIAL AND METHODS}

\section{DUNALIELLA CULTURE}

All three reactors were inoculated with $600 \mathrm{~mL}$ of pure Dunaliella salina (SAG:42.88) grown in Dunaliella medium (=Dun) at $250 \mathrm{C}$ and a $\mathrm{pH}$ of 7.0. The inoculum was grown to a 1 x107 cells/mL, with an initial cell density of $2.8 \times 105$ cells $/ \mathrm{mL}$

\section{GROWTH MEDIUM}

The modified Dunaliella growth medium was used for inoculum and algae growth experimentation. All the nitrogen uptake by the algal cells was provided through inlet simulated gas. Dunaliella salina was grown in modified Dunaliella medium. A nitrogen free stock solution was prepared with K2HP04, $0.1 \mathrm{~g} / 100 \mathrm{~mL} .20 \mathrm{~mL}$ of this nutrient was mixed with $30 \mathrm{~mL}$ of the soil extract and $930 \mathrm{~mL}$ artificial seawater to make a liter solution. The growth medium was given in Table 1. 


\begin{tabular}{|l|l|l|}
\hline Table1. Modified Dunaliella growth medium \\
\hline Component & $\begin{array}{l}\text { Stock sol. } \\
(\mathrm{g} / 100 \mathrm{~mL})\end{array}$ & $\begin{array}{l}\text { Nutrient concentrate } \\
\text { ion }(\mathrm{mL})\end{array}$ \\
\hline KOH & 0.1 & 20 \\
\hline Soil extract & 30 & - \\
\hline Artificial seawater & 930 & - \\
\hline
\end{tabular}

Operating conditions of the reactor

\section{Case 1: pure N02 feed source:}

N02 gas diluted with ambient air was used as the simulated flue gas for the first run. As the boiling point of $\mathrm{NO}_{2}$ is approximately $20^{\circ} \mathrm{C}$ at atmospheric pressure; $\mathrm{NO}_{2}$ was initially released as a liquid in the tubing. NO2 was blended with 3Lpm of air to get NOx concentrations of $100 \mathrm{ppm}, 200 \mathrm{ppm}, 350 \mathrm{ppm}$ in photobioreactors 1a, 1b, and 1c respectively. Experimental conditions were given in Table 2.

\begin{tabular}{|l|l|l|l|}
\hline \multicolumn{4}{|c|}{ Table 2. Experimental conditions for case 1} \\
\hline Setting & Reactor $1 \mathrm{a}$ & Reactor $1 \mathrm{~b}$ & Reactor $1 \mathrm{c}$ \\
\hline Inlet $\mathrm{NO}_{\mathrm{x}}(\mathrm{ppm})$ & 100 & 200 & 350 \\
\hline $\begin{array}{l}\text { Inlet Gas Flow } \\
\text { Rate }(\mathrm{Lpm})\end{array}$ & 3 & 3 & 3 \\
\hline $\mathrm{pH}$ & $7-8$ & $7-8$ & $7-8$ \\
\hline Temperature $\left({ }^{\circ} \mathrm{C}\right)$ & 20 & 20 & 20 \\
\hline
\end{tabular}

The simulated gas entered each photobioreactor through a sparger, $\mathrm{pH}$ was maintained in the range of 7.0 to 8.0 using $\mathrm{CO2}$. The carbon dioxide feed was monitored by separate valves to each reactor which was controlled based on the $\mathrm{pH}$ in the reactor. NOx removal rates were monitored for four days. The reactors were illuminated with three $1 \mathrm{~m}$ long fluorescent white lights emitting, a total of 2700 Klux.

\section{Case 2: Gas feed source calibration:}

For the case 2, the reactors were inoculated before to the start of NOx loading and left for two days during which, only ambient air was supplied to the system. NOx was given from NO2 calibration gas cylinders compris-

\begin{tabular}{|l|l|l|l|}
\hline \multicolumn{4}{|l|}{ Table 3. Experimental conditions for case 2 } \\
\hline Setting & $\begin{array}{l}\text { Reactor } \\
2 \mathbf{a}\end{array}$ & $\begin{array}{l}\text { Reactor } \\
\text { 2b }\end{array}$ & $\begin{array}{l}\text { Reactor } \\
\text { 2c }\end{array}$ \\
\hline Inlet $\mathrm{NO}_{\mathrm{x}}(\mathrm{ppm})$ & 25 & 50 & 120 \\
\hline Inlet $\mathrm{Gas}$ Flow Rate $(\mathrm{Lpm})$ & 3 & 3 & 3 \\
\hline Influent $\mathrm{CO}_{2}(\mathrm{~g})(\mathrm{ppm})$ & 400 & 400 & 400 \\
\hline $\mathrm{pH}$ & $7-8$ & $7-8$ & $7-8$ \\
\hline Temperature $\left({ }^{\circ} \mathrm{C}\right)$ & 20 & 20 & 20 \\
\hline
\end{tabular}

ing 5000 ppm and 9000 ppm N02 concentration. Thus, in this case, the need for the liquid NO2 trap was ignored as the gas mixture was already in a vapor state. Thus, pumping calibration gas achieved steady inlet concentrations. Experimental conditions were given in table3. The calibrated NO2 is blended using air for the required NOX concentrations. The calibrated gases were supplied to the reactor at $3 \mathrm{Lpm}$, having N02 concentrations of 25 ppm, 50 ppm, 120 ppm respectively. The concentration range was chosen to resemble real-time power plant NOx concentrations. Two aquarium stones of $12 \mathrm{~cm}$ were used to diffuse the gas into the reactor. $\mathrm{CO} 2$ was supplied in the system, at a concentration of 400ppm until the $\mathrm{pH}$ remains 7 However when the $\mathrm{pH}$ is below 7, the $\mathrm{pH} 7$ was maintained using $1.0 \mathrm{~g} / \mathrm{L}$ solution of sodium bicarbonate (NaHCO3). The system was run for six days after loading of NOx. Influent and effluent concentrations of $\mathrm{NO}$ and $\mathrm{NO} 2$ in gas samples were measured using an analyser, (Testo 350-S/-XL, USA).

\section{RESULTS AND DISCUSSION}

\section{NOX REMOVAL EFFICIENCY}

\section{Case 1: pure N02 feed source}

In this case, the reactors were fed with pure NO2 which is delivered as a liquid at room temperature and then the collected vapors were diluted with air. Using pure NO2 gas, actual average inlet concentrations for reactors $1 \mathrm{a}$, $1 \mathrm{~b}$, and 1c were $108 \mathrm{ppm}, 35 \mathrm{ppm}, 70 \mathrm{ppm}$ respectively (Table 4). Fig. 1 shows the Dunaliella growth curve in reactors $1 \mathrm{a}, 1 \mathrm{~b}$, and $1 \mathrm{c}$ during 90 -hour run.

\begin{tabular}{|c|c|c|c|c|}
\hline \multicolumn{5}{|c|}{ Table 4. Influent and effluent $\mathrm{NO}_{\mathrm{x}}$ concentrations in reactors } \\
\hline Reactor & $\begin{array}{c}\text { Ratio } \\
\text { (NO:NO2) }\end{array}$ & $\begin{array}{c}\text { Inlet NOx (g) } \\
\text { Conc }(\mathrm{ppm})\end{array}$ & $\begin{array}{c}\text { Outlet } \mathrm{NO}_{\mathrm{x}}(\mathrm{g}) \\
\text { Conc }(\mathrm{ppm})\end{array}$ & $\begin{array}{c}\text { Average removal } \\
\text { Conc (\%) }\end{array}$ \\
\hline 1a & 0.47 & $108 \pm 55$ & $47 \pm 33$ & 49 \\
\hline 1b & 0.15 & $35 \pm 16$ & $15 \pm 12$ & 51 \\
\hline 1c & 0.35 & $70 \pm 32$ & $8 \pm 7$ & 81 \\
\hline 2a & 0.038 & $27 \pm 6$ & $11 \pm 4$ & 59 \\
\hline 2b & 0.035 & $57 \pm 9$ & $2 \pm 8$ & 96 \\
\hline 2c & 0.043 & $126 \pm 12$ & $7 \pm 11$ & 95 \\
\hline
\end{tabular}




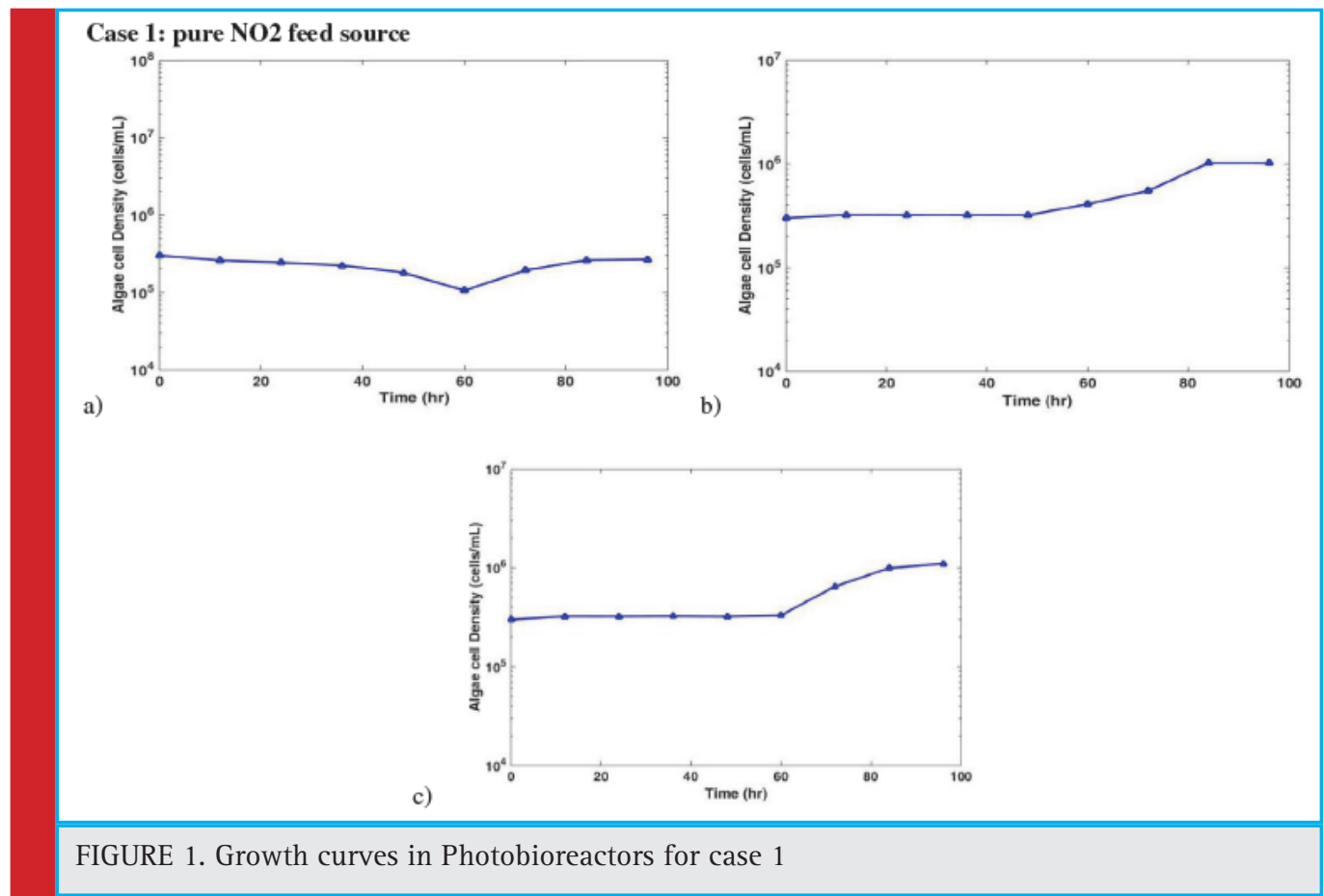

All three reactors began with $2.8 \times 10^{5}$ cells $/ \mathrm{ml}$. As shown in Fig. 1, the culture in reactor 1a began exhaustive during the first 24 hours, therefore, the cells never attained a density greater than the initial. The maximum cell densities, for $1 \mathrm{~b}$, 1c were $1.46 \times 106$ cells $/ \mathrm{mL}$ and $1.48 \times 106$ cells/mL respectively. Table 3 presents the NOx removal data for the reactors under case 1 . Inlet and out- let NOx in Table 3 is the summation of measured NO and NO2 concentrations in the inlet and outlet streams. The efficiency of NOx removal by the algal system is based on total nitrogen through the reactor system and not on any particular NOx component. Therefore, removal percent of total NOx is only considered in the analysis. Reactor 1a obtained an average NOx removal of 49\%,

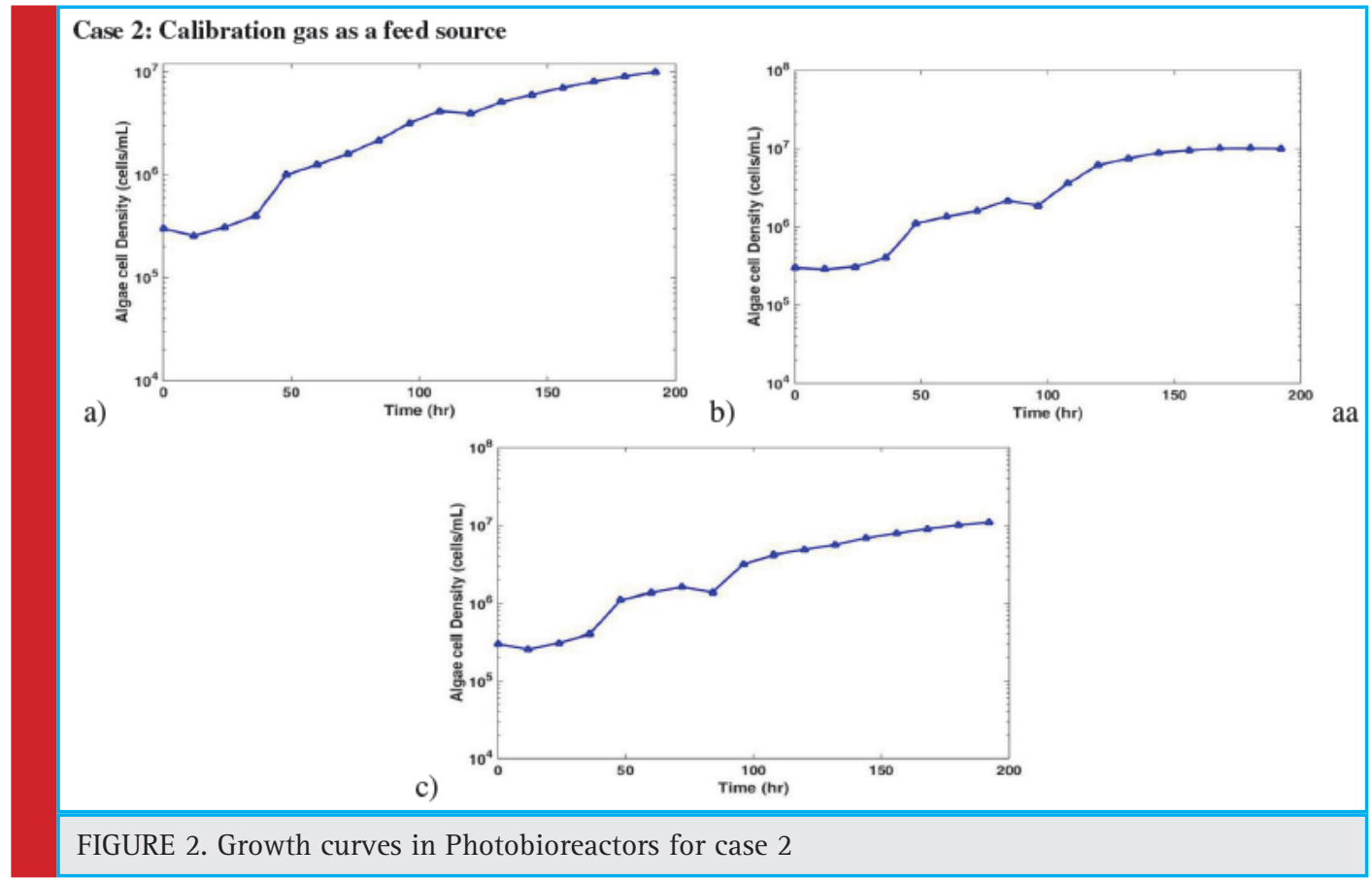




\begin{tabular}{|c|c|c|}
\hline Photo-bioreactor & TSS Initial (mg/L) & TSS Final $(\mathrm{mg} / \mathrm{L})$ \\
\hline $2 a$ & 6.0 & 210 \\
\hline $2 b$ & 5.7 & 243 \\
\hline $2 c$ & 6.3 & 222 \\
\hline
\end{tabular}

Reactor $1 \mathrm{~b}$ achieved an average 51\% NOx removal, and Reactor 1c has removed an average of $81 \%$ of inlet NOx. The average NOx removal efficiency for the first $60 \mathrm{~h}$ was 39\%, but the average removal for the last 25 hours was 52\%. As the algal culture was declining, removal of NOx could be associated with the dissolution of NO2 into the medium.

Reactors $1 \mathrm{~b}$ and 1c presented moderate growth following an extended lag phase, as shown in the figure 1. Algae in reactors $1 \mathrm{~b}, 1 \mathrm{c}$ has not truly experienced log phase, and the run was ended after 90 hours.

\section{Case 2: Calibration gas as a feed source}

As shown in Fig. 2 all three reactors began with a cell concentration of $2.8 \times 105$ cells $/ \mathrm{mL}$ for three reactors $2 \mathrm{a}$, 2b, and 2c .Maximum cell densities were $1.24 \times 107$ cells/ $\mathrm{mL}, 1.46 \times 107$ cells $/ \mathrm{mL}$ and $1.72 \times 107$ cells/mL respectively. To overcome some of the problems that appeared from using pure NO2 gas in case 1, NO2 calibration gases of 5000ppm and $10000 \mathrm{ppm}$ NO2 were used to supply NOx for case 2. This allowed for accurate NOx loading concentrations. Actual NOx Loading rates for case 2 were $27 \mathrm{ppm}, 57 \mathrm{ppm}$ and $126 \mathrm{ppm}$ for reactors $2 \mathrm{a}, 2 \mathrm{~b}$, and $2 \mathrm{c}$ respectively.

The data in Table 4 presents the removal of NOx for the reactors (case 2). Inlet and outlet NOx in Table 4 is the summation of measured NO and NO2 concentrations in the inlet and outlet streams. Reactor 2 a got an average NOx removal of 59\% reactor 2 b got an average $96 \%$, and reactor $2 \mathrm{c}$ was able to remove an average of $95 \%$ of inlet NOx. The lag phase was reduced to less than 24 hours due to delay in NOx loading, and log phase was attained between 24 and 48 hours. NOx loading started

\begin{tabular}{|l|l|l|l|}
\hline \multicolumn{5}{|l|}{ Table 6. Nitrogen mass balance data } \\
\hline & $\begin{array}{l}\text { Reactor } \\
2 \mathrm{a}\end{array}$ & $\begin{array}{l}\text { Reactor } \\
2 \mathrm{~b}\end{array}$ & $\begin{array}{l}\text { Reactor } \\
2 \mathrm{c}\end{array}$ \\
\hline $\mathrm{NO}_{\mathrm{x}}$ Input & 890 & 1740 & 3450 \\
\hline $\mathrm{NO}_{\mathrm{x}}$ Output & 450 & 60 & 90 \\
\hline $\begin{array}{l}\mathrm{N} \text { Consumed from } \mathrm{NO}_{\mathrm{x}} \text { gas } \\
\text { phase }\end{array}$ & 440 & 1680 & 3360 \\
\hline Initial $\mathrm{N}_{\text {in } \text { growth medium }}$ & 23 & 22 & 23 \\
\hline Final $\mathrm{NO}_{3}-$ & 27 & 14 & 48 \\
\hline Final $\mathrm{NO}_{2}-$ & 74 & 13 & 163 \\
\hline $\begin{array}{l}\text { Net Accumulation of } \mathrm{NO}_{3}- \\
+\mathrm{NO}_{2}-\end{array}$ & 78 & 5 & 188 \\
\hline Initial Organic $\mathrm{N}$ & 0 & 0 & 0 \\
\hline Final Organic $\mathrm{N}$ & 310 & 750 & 1140 \\
\hline $\begin{array}{l}\mathrm{N} \text { Accumulated in Algal } \\
\text { Cells }\end{array}$ & 310 & 750 & 1140 \\
\hline Total $\mathrm{N}$ Accumulated & 388 & 755 & 1228 \\
\hline $\begin{array}{l}\text { Mass Balance } \% \mathrm{NO}_{\mathrm{x}} \\
\text { uptake accounted for) }\end{array}$ & $88 \%$ & $45 \%$ & $36 \%$ \\
\hline
\end{tabular}

at 48 hours, and three reactors showed continued growth, but with a significant decline in growth rate (Fig. 2).

Total suspended solids (TSS) for initial and final samples were taken to quantify algal growth and to estimate the nitrogen content of the cells. The results were summarized in the Table 5. Total suspended solid results show that 37 fold average mass growth was accomplished over the 190-hour run. For nitrate and nitrite concentrations, liquid samples from case 2 were analyzed, and the results were shown in Fig.3. Nitrate was completely drained in all three reactors before NOx was loaded into the system at 49 hours. Nitrogen source available for algal growth only after that point was from dissolved N02. Initial and final total organic nitrogen content of the algal cultures was used to estimate the uptake of nitrogen by algae and to determine the nitrogen content of the cells. These analyses summarized in the table: the cells in reactors $2 \mathrm{a}, 2 \mathrm{~b}$, and $2 \mathrm{c}$ were found to contain $6.2 \%, 4.1 \%$, and $7.9 \%$ nitrogen respectively.

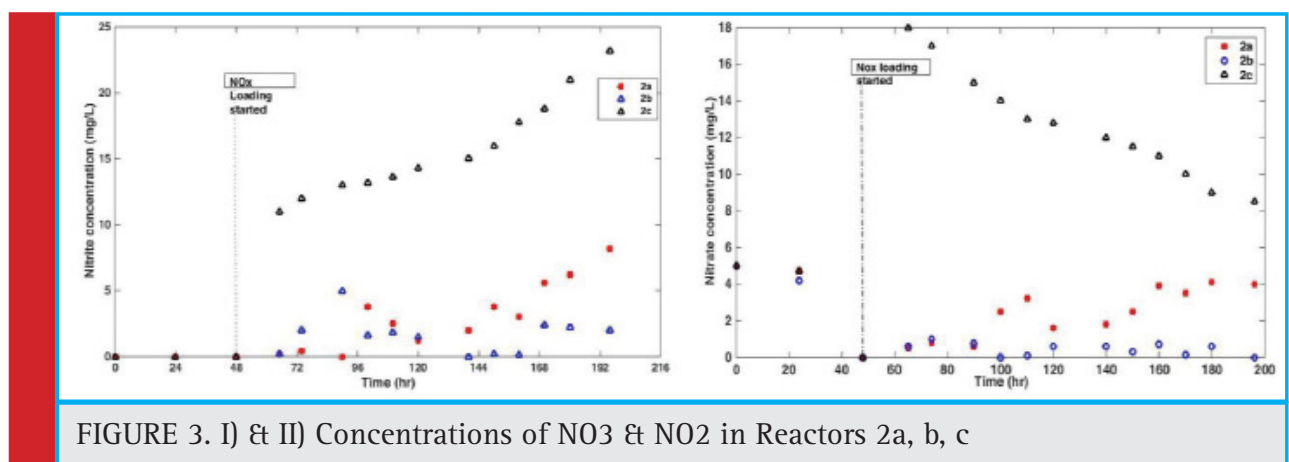

678 NOX REMOVAL USING DUNALIELLA SALINA ALGAE IN PHOTOBIOREACTORS 
A mass balance of nitrogen was conducted to assess the effect of NOx through the system. In reactor $2 a$, the mass balance alleged for $88 \%$ of the observed NOx removal, as slightly more nitrogen was found in the cells and growth medium than entering the system.

For reactors $2 \mathrm{~b}$ and 2 c, only $45 \%$ and 36\% respectively of the nitrogen that entered the system was found in the cells and growth medium. NOx feed stream: Loading NOx at a particular concentration tested to be very difficult for the first case, as can see by more standard deviations in the table 6:. In the first case, NOx was given from a pure NO2 cylinder, and vapors from this liquid were pumped using peristaltic pumps into the reactors. To overcome large deviations in concentration, case 2 was operated using calibration gases. Data analysis considered only in case 2 because of the NOx feed was not consistent during case1.Nitrogen mass balance data summarized in Table 6 . The only difference in the three reactors in case 2 was the loading rates of NOx.

NOx removal: In case 2, NOx removal rates are 59\%, $95 \%, 96 \%$ for reactors $2 \mathrm{a}, 2 \mathrm{~b}$, and $2 \mathrm{c}$ respectively. Only $59 \%$ NOx removal was achieved in reactor $2 \mathrm{a}$, which had the lowest NOx loading rate. NOx loading rates were different in three reactors. Aqueous nitrate and nitrite concentrations in the reactors are shown in Figure3.

Cell growth: The average specific growth rate for the first 2 days in reactors $2 \mathrm{a}, 2 \mathrm{~b}$, and $2 \mathrm{c}$ was $0.03,0.06$, 0.12 respectively, the average specific growth rates for the same period in reactors $1 \mathrm{a}, 1 \mathrm{~b}$ were both negative, the growth curves of case 2 presented in Fig. 3, after loading NOx, growth rates started to decline in all three reactors and never achieved the value as before NOx loading, and this declining growth is proportional to the NOx concentration entering the system. Approximately 48 hours of NOx loading, the inlet concentrations of NOx do not affect algal growth. Algae took nearly 48 hours to adopt new nitrogen source.

Nitrate /Nitrite: The algae was able to take nitrate in solution before the loading of into the reactors. After 48 hours Nitrogen source is available only from NOx. The steady fall in NO3- concentrations and NO2- accumulation in reactor $2 c$ suggests that algae preferred N03- as its nitrogen source over N02-.

\section{CONCLUSION}

The primary purpose of this study was to test the hypothesis that Dunaliella can grow on nitrogen from dissolved NO2 as its only nitrogen source for cell synthesis. Dunaliella grew used only nitrate / nitrite generated by the NOx dissolution for cell synthesis, reaching a maximum cell density of $1.75 \times 107$ cell $/ \mathrm{ml}$. A reactor with lower NO2 loading concentrations resulted in lower NOx removal rates, for this reactor, nitrate was not accumulated as efficiently as a similar with grated NOx loading. In case 2: cell growth of mass between $1850 \mathrm{mg} / \mathrm{L}$ to $198 \mathrm{mg} / \mathrm{L}$. Nitrogen was removed from gaseous NOx at a rate of $0.06-0.45 \mathrm{mg} \mathrm{N} / \mathrm{mg}$ cell growth. Assuming a $700 \mathrm{MW}$ natural gas fired power plant can produce up to $1,70,000 \mathrm{~m} 3 / \mathrm{h}$ of flue gas with approx. 50ppm NOx concentrations, growth of a minimun $110 \mathrm{~kg}$ algal cell $/ \mathrm{h}$ would be required to treat this stream.

\section{REFERENCES}

Attilo Converti et al (2009) Effect of temperature and nitrogen concentration on the growth and lipid content of Nanochloropsi lata and Chlorella vulgaris for biodiesel production Chemical Engineering and Processing Vol.48 1146-1151

Harter H J (2013) Carbon and nitrogen mass balance during flue gas treatment with Dunaliella salina cultures, Journal of Applied Phycology, Volume 2 : 359-368

Hong-Wei Yen (2015) CO2, NOx and SOx removal from flue gas via microalgae cultivation, Biotechnology Journal Vol. 10: 890-899.

Kaitlyan D (2018) The fate of nitrogen through algal treatment of landfill leachate, Algal Research, Volume 30: 50-58

Kethineni, C. (2017) Development of Sequential Processes for Multiple Product Recovery from Microalgae, Industrial Biotechnology Vol 14 No 2:94-99

Lee, Y. N., \&t Schwartz, S. E. (1981) Reaction kinetics of nitrogen dioxide with liquid water at low partial pressure. The Journal of Physical Chemistry.Vol 85 No7: 840-848

Miller, J. S., \& Ledakowicz, S. (2010) Trends in NOx abatement: A review. Science of the Total Environment, Vol 408 No 19:3976-3989.

Mulholland, M. R., \&t Lomas, M. W. (2008) Nitrogen Uptake and Assimilation. In D. G. Capone, D. A. Brown, M. R. Mulholland, \& E. J. Carpenter (Eds.), Nitrogen in the marine environment Amsterdam: Elsevier Academic Press. (2nd Ed.: 303-384).

Nagase, H. (1997) Characteristics of biological NOx removal from flue gas in a Dunaliella tertiolecta culture system. Journal of Fermentation and Bioengineering,Vol. 83 No 5: 461-465

Raja R S. Hemaiswarya, R. Rengasamy (2007) Exploitation of Dunaliella for $\beta$-carotene production. Applied Microbiology \& Biotechnology.Vol 74 No 3: 517-523

Ronda JI (2014) A growth inhibitory model with $\mathrm{SO}_{\mathrm{x}}$ influenced effective growth rate for estimation of algal biomass concentration under flue gas atmosphere, Bioresource Technology, Volume 152: 283-291

Skalsa K (2010), Trends in NOx abatement. Implementation of stringent regulations of NOx emission requires the development of new technologies for NO $x$ removal from exhaust gases.Science of The Total Environment Vol. 408: 3976-3989 
Tianpei Li and Gang Xu (2016). The acclimation of Chlorella to high-level nitrite for potential application in biological NOx removal from industrial flue gases. Journal of Plant Physiology Vol. 195: 73-79.

Tomasz T \& Hidehiro Kumazawa (2016) Reactivity of nanosize zinc powder in the aqueous solution of (FeIII(Edta)
(H20) Science of The Total Environment Vol. 628-629: 870881

Yuxuan Zhu (2018), Biological activities and nitrogen and phosphorus removal during the Anabaena flos-aquae biofilm growth using different nutrient form, Bioresource Technology, Volume 251: 7-12 